\title{
SURVIVAL AND GROWTH OF MILKFISH (Chanos chanos) LARVAE UNDER DIFFEREN'T COLOUR VALUES OF ORANGE
}

\author{
Taufik Ahmad") and Titiek Aslianti*)
}

\begin{abstract}
An orange painted tank was proved to be suitable for rearing milkfish larvae. However, light intensity was suspected to affect the suitability such tanks. The research investigated the value of the orange colour suitable for milkfish larval rearing under all light intensities. The values of orange were developed by mixing the colour with white (paleness) or black (darkness) at 75:25, 50:50, and 25:75. Including pure orange, white, and black, there were 9 values of orange i.e., $+1,+3 / 4,+1 / 2,+1 / 4,0,-1 / 4,-1 / 2,-3 / 4$, and -1 as treatments. The treatments were arranged in a randomized block design having three replicates differentiated by light intensity. The density of the eggs was 10.000 per tank filled with $500 \mathrm{~L}$ sea water. There was no significant effect $(p>0.05)$ of paleness or darkness of orange colour on survival rate of the fry, though there was a significant ( $p$ $<0.05)$ decrease in survival rate in the white painted tank. The survival rate of the larvae in the tank painted pale orange (a mixture of orange and white at 75:25) tended to be higher than the ones produced in the other tanks. The survival rate of the fry in orange tanks ranged from 50 to $66 \%$. The lowest survival rate. $3.31 \%$. was obtained in the white painted tank. All values of orange colour tested were suitable for milkfish larval rearing tanks.
\end{abstract}

KEYWORDS: Milkfish larvae; colour values.

\section{IN'TRODUC'TION}

The colour of the larval rearing tank is among the dominant factors affecting the survival and growth of milkfish larvae. The hue of the tank-wall colour reflects a certain amount of energy which is suspected of influencing the ability of fish to identify food organisms. Differences in tank-wall colour change the contrast of food items against the background and so change the ability of the larvae to feed. In turn this would influence the survival and growth rate of the larvae.

According to Halsey et al. (1974), in the Munsell system, every colour consists of hue, chroma, and value. The value of a hue is an increase or a decrease of its paleness or darkness which is related to the neutral colour such as white and black. When a hue is mixed with white, the value increases, and in the opposite when mixed with black, the value decrease.

In rearing fish larvae, the value of a hue is very important because it affects the contrast between food organisms and background, and therefore affects visual discrimination (Lythgoe, 1980; Ostrowski 1989) which may bring about the decrease on feeding rate. A decreasing feeding rate would decrease the survival and growth rate of the larvae. Bagarinao (1991) found that the milkfish eyes are most sensitive to wavelengths between orange and yellow. Ahmad et al. (1994) have shown an orange tank with

*) Researcher of the Research Institute for Coastal Aquaculture. Maros 
wavelength $590 \mu \mathrm{m}$ is able to support $60 \%$ survival rate of milkfish larvae, which is significantly higher than the survival rate for any other tank colours.

Improved contrast between food organism and background would also be expected to lower the cases of "silvery-eyes" abnormality (Ahmad et al., 1994). The silvery eyes are an indication of blindness, thought to be caused by high light intensities (Noakes and Godin, 1988). The number of silvery-eyes cases could be overcome by proper application of orange tanks.

\section{MATERIALS AND METHODS}

Twenty seven $1.0 \mathrm{~m}^{3}$ cylindrical fibreglass tanks painted different values of orange were used and arranged in a randomized block design with each treatment having 3 replicates.

The values of orange were obtained by mixing orange (itself a mixture of 2 pure pigments, mercedez red and light chrome yellow, in $50 \% / 50 \%$ ) with neutral colours, either white or black. The mixing ratios for orange to white or black were 75:25, 50:50, and 25:75, resulting in 6 different values of orange, namely, $+1 / 4,+1 / 2,+3 / 4$ for pale and $-1 / 4,-1 / 2,-3 / 4$ for dark. The other values tested were 0 for unmixed orange, +1 for pure white, and - 1 for pure black.

Each tank was filled with $500 \mathrm{~L}$ of sea water (34 ppt) mixed with algae (Nannochloropsis occulata) and rotifers (Brachionus plicatilis) as larval food. Ten thousands milkfish eggs obtained from the same spawner were put into each tank. Feeds $\left(10^{4}\right.$ cells algae $/ \mathrm{mL}$ and 5 rotifers $/ \mathrm{mL}$ ) were given on the second day after the milkfish eggs hatched. Dead food and faeces of the larvae were siphoned away every 5 days and at the same time $70 \%$ of the water was exchanged.

The survival rate of larvae was counted by dividing the number of 21-day old larvae by the number of eggs hatched. It was assumed that the egg quality and hatching rate were equal in all treatments. The daily instantaneous growth rate of larvae was calculated with the equation developed by Yamaguchi (1978).

\section{RESULTS AND DISSCUSSION}

\section{Survival Rate}

Survival rate tended to be increased by the addition of white to orange. In the other words, the pale orange tanks supported the survival of milkfish larvae better than the pure orange tank. However, in the tank painted pure white (value +1 ) the survival rate was only $3.31 \%$, and the larvae were weak and did not respond to physical shock. In contrast, increasing darkness of colour did not affect either survival or growth rate (Table 1).

The highest survival rate seems to be achieved in the tank painted orange at value $+1 / 4$, though statistically it was not significantly different $(p>0.5)$ from the survival rate of all but tanks painted +1 . The increase in value as a result of white addition beyond $75 \%$ is suspected to decrease the contrast between feed organism and its background colour. This would make it difficult for the milkfish larvae to identify its food and eventually lower the predation ability (Bagarinao, 1991).

Based on the performance of larvae in each value of orange (Figure 1) the tank painted orange at values $1 / 4$ to $1 / 2$ seems to be better than the other tanks for rearing milkfish larvae. Both survival rate and daily instantaneous growth rate decreased steadily at values higher than $+1 / 2$. In the pure white tanks (value +1) many larvae died due to starvation, proven by empty stomachs and "silvery-eyes" which is an indication of blindness caused by high light intensity and malnutrition (Noakes and Godin, 1988). 
Table 1. Average survival and instantaneous growth rate of milkfish (Chanos chanos) larvae reared in the tank painted different values of orange.

\begin{tabular}{ccc}
\hline Colour & $\begin{array}{c}\text { Level of value } \\
(\mathbf{\%})\end{array}$ & $\begin{array}{c}\text { Survival rate* } \\
(\%)\end{array}$ \\
\hline Pure white & $+\mathbf{1}$ & $3.31^{\mathrm{b}}$ \\
$+3 / 4$ & $52.91^{\mathrm{a}}$ \\
$+\mathbf{1 / 2}$ & $61.84^{\mathrm{a}}$ \\
& $+\mathbf{1 / 4}$ & $66.54^{\mathrm{a}}$ \\
Pure orange & $\mathbf{0}$ & $50.75^{\mathrm{a}}$ \\
& $-\mathbf{1 / 4}$ & $60.98^{\mathrm{a}}$ \\
& $-\mathbf{1 / 2}$ & $58.51^{\mathrm{a}}$ \\
& $-\mathbf{3 / 4}$ & $62.20^{\mathrm{a}}$ \\
& -1 & $64.92^{\mathrm{a}}$ \\
\hline
\end{tabular}

* Values followed by similar letter are not significantly different $(p>0.05)$

The highest survival rate of milkfish fry in this experiment $(66.54 \%)$ was higher than in previous experiments. Giri et al. (1986) reported that the survival rate of milkfish fry in a transparent fibreglass tank was $51.10 \%$, while Prijono et al. (1993) obtained 50.05\% survival in a black tank. With live rotifers as larval feed, the survival rate of milkfish larvae in a black tank could only achieve $42.73 \%$ (Aslianti et al., 1993a). The milkfish fry production data (Table 2 ) in several different coloured tanks have shown that the orange painted tank was more suitable for milkfish larval rearing than others.

Table 2. Survival rate of milkfish (Chanos chanos) fry in various coloured larval rearing tanks.

\begin{tabular}{ccc}
\hline Colour of tank & Survival rate (\%) & Source \\
\hline Transparant & $\mathbf{5 1 . 1 0}$ & Giri et al. (1986) \\
Black & $\mathbf{5 0 . 0 5}$ & Prijono et al. (1993) \\
Black & $\mathbf{4 2 . 7 3}$ & Aslianti et al. (1993a) \\
Red & $\mathbf{4 6 . 6 0}$ & Ahmad et al. (1994) \\
Orange & $\mathbf{6 5 . 7 5}$ & Ahmad et al. (1994) \\
Yellow & $\mathbf{5 3 . 7 2}$ & Ahmad et al. (1994) \\
\hline
\end{tabular}




\section{Growth Rate}

Increasing paleness of orange tended to improve the fry sizes both in total length and body weight. The longest fry, $13.8 \mathrm{~mm}$, which was also the heaviest in value $+1 / 2$ ('Table 3 ). Since there is no significant difference in survival rate between values, except for pure white, the density of the larvae is assumed not to affect growth. The contrast between tank wall colour background and colour of food particles is interpreted as increasing the ability of the larvae to identify food. Consequently, the higher the feed contrast, the higher the predation rate, and eventually the higher growth rate. Figure 2 and 3 showing the difference of growth of milkfish larvae reared in the most suitable (value $+1 / 2$ ) and in the most unsuitable tanks (value +1 ). In those figures, value 0 representing the most suitable colour for milkfish larval rearing tank (orange) reported by Ahmad et al. (1994).

According to Munz (1971) and Guthrie (1986) the fish retina, the main organ to detect light stimulation, is relatively complex, consisting of cone cell photoreception for colour together with bipolar cell ganglia. The eyes of fish larvae pass through very complex functional changes during early larval growth (Kawamura and Hara, 1980; Kawamura and Shimada, 1980. Kawamura, 1984; Fernald, 1985). Ecological factors such as temperature, food availability, and light in its turn also affect growth rate (Brett, 1979).

Milkfish fry have well developed eyes with a duplex retina which is spatially differentiated. The highest density and thickness of cells is located (Bagarinao, 1991). Even though rod intensity is generally low and with a spectrum sensitivity peak between 492-522 $\mu \mathrm{m}$ and 582-621 $\mu \mathrm{m}$, milkfish fry could differentiate colour (Kawamura and Nishimura, 1980). According to Durve (1986), the fry of most fish could identify white, red, and light green colours. However, the ratio of rods to cone (which is low in milkfish larvae, 1.4-2.0) is suspected to prevent milkfish larvae from identifying food in environments dominated by these colours.

Tabel 3. Initial and final total length and body weight of milkfish (Chanos chanos) larvae reared under different values of tank wall colour.

\begin{tabular}{ccccc}
\hline $\begin{array}{c}\text { Level of } \\
\text { value }\end{array}$ & $\begin{array}{c}\text { Total length }(\mathbf{m m}) \\
\text { Initial } \\
\text { (5- day old) }\end{array}$ & $\begin{array}{c}\text { Final } \\
\text { (21-day old) }\end{array}$ & $\begin{array}{c}\text { Body weight }(\mathbf{m g}) \\
\text { Initial } \\
\text { (5-day old) }\end{array}$ & $\begin{array}{c}\text { Final } \\
\text { (21-day old) }\end{array}$ \\
\hline+1 & 4.83 & 10.76 & 0.50 & 6.40 \\
$+3 / 4$ & 4.88 & 12.59 & 0.68 & 8.14 \\
$+1 / 2$ & 4.88 & 13.87 & 0.83 & 14.57 \\
$+1 / 4$ & 4.89 & 12.25 & 1.12 & 9.67 \\
0 & 5.05 & 12.38 & 1.03 & 10.20 \\
$-1 / 4$ & 4.69 & 12.30 & 0.80 & 12.63 \\
$-1 / 2$ & 5.11 & 13.35 & 0.95 & 9.11 \\
$-3 / 4$ & 5.77 & 11.94 & 0.99 & 7.88 \\
-1 & 5.03 & 13.06 & 1.03 & 13.55 \\
\hline
\end{tabular}




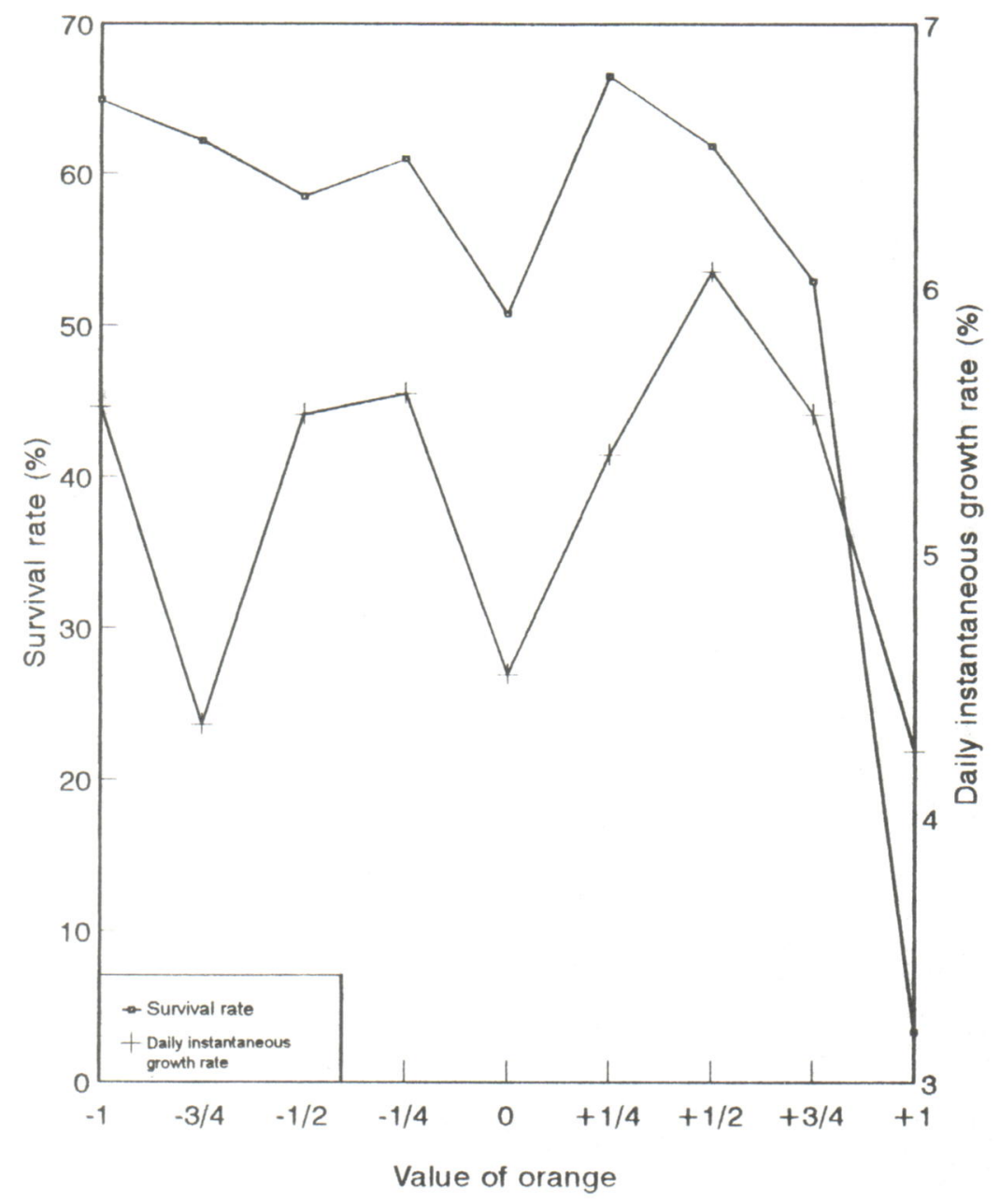

Figure 1. Survival rate and daily instantaneous growth rate of milkfish larve reared under different values of orange 


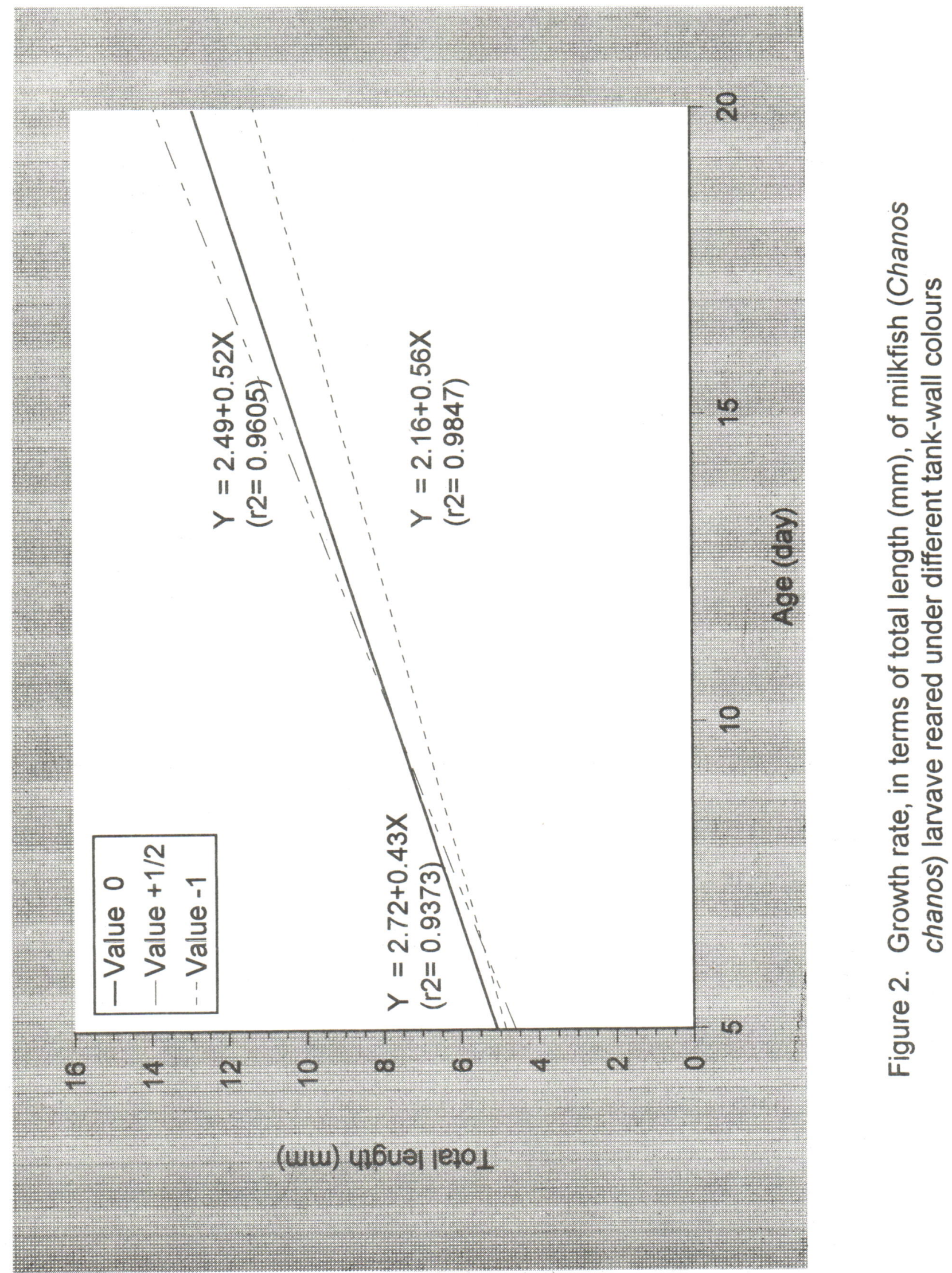




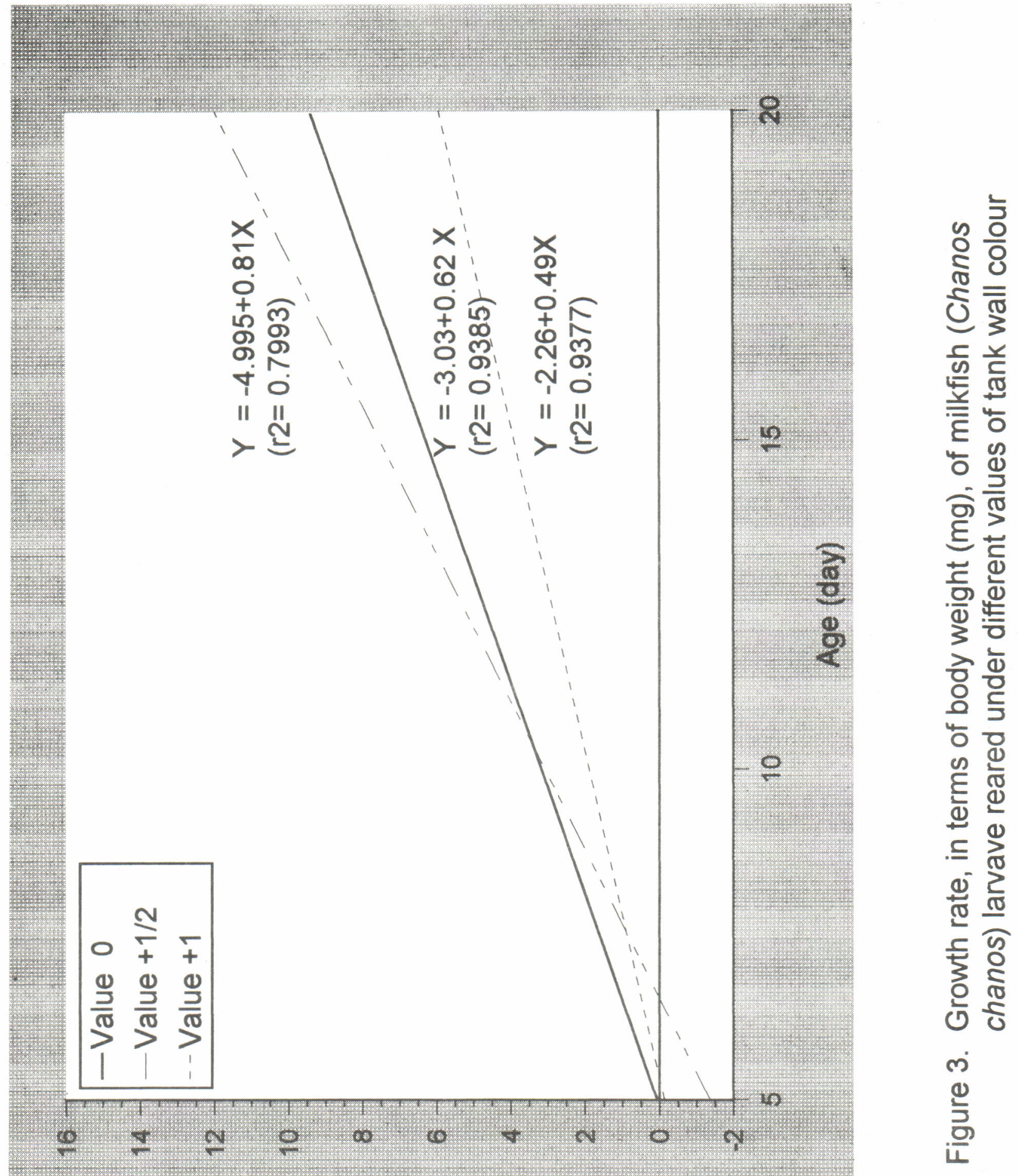

(6w) 14 біем fрog 
Bagarinao (1991) reported that the total length of wild-caught milkfish fry, which performed and looked like the 21-day old hatchery-bred fry, ranged between 5.8 and $14.6 \mathrm{~mm}$. Prijono et al. (1993) observed the total lengths of 21 days old hatchery-bred larvae reared in transparent and black painted fibreglass tank were 13.44 and 11.07 $\mathrm{mm}$, respectively.

Total length and body weight which were not statistically different between hatchery-bred and wild fry (Table 4) suggest that hatchery-bred milkfish fry are not inferior to wild ones. Among the hatchery fry, the ones grown in pale orange tanks tended to be bigger and healthier.

\section{CONCLUSIONS AND RECOMMENDA- TIONS}

\section{Conclusions}

1. The survival and growth rates of milkfish fry were not affected by increases in darkness of orange used for colouring the wall of the larval rearing tank.

2. The addition of more than $75 \%$ white to orange (value more than $+3 / 4$ ) for colouring larvae rearing tanks reduces the survival and growth rate of milkfish larvae.

3. Larval rearing tanks painted white are not suitable for milkfish fry production.

\section{Recommendations}

1. To maintain high survival and growth rates, milkfish larvae should be raised in tanks painted orange with the value not exceeding $+3 / 4$ and even better at $+1 / 4$ to $+1 / 2$.

2. To improve the performance of orange hue for milkfish larvae rearing, experiments on chroma should also be carried out.

\section{ACKNOWLEDGEMENT}

The assistance of Dedi Rohaniawan, I Gusti Putu Oka, and Made Parya in providing natural feed and in carrying out routine siphoning of water media is highly appreciated. Thanks to Kasmawati and Rosmiati who diligently typed the manuscript.

\section{DAFTAR PUSTAKA}

Ahmad, T.; T. Aslianti; dan D. Rohaniawan. 1994. Laju pertumbuhan dan kelangsungan hidup nener, Chanos chanos Forssk dalam berbagai nuansa warna wadah. J. Penelitian Budidaya Pantai 10. (1) : 123-134.

Aslianti, T.; A. Prijono; dan T. Ahmad. 1993a. Pengaruh pemberian pakan alami dan pakan buat-an terhadap kelangsungan hidup larva bandeng, Chanos chanos Forsskal. J. Penelitian Budidaya Pantai 9 (1): 81-90.

Table 4. Average size of wild caught and 21 days old hatchery-bred milkfish (Chanos chanos) larvae.

\begin{tabular}{lccl}
\hline Origin & $\begin{array}{c}\text { Total length } \\
(\mathbf{m m})\end{array}$ & $\begin{array}{c}\text { Body weight } \\
(\mathbf{m g})\end{array}$ & \multicolumn{1}{c}{ Source } \\
\hline Wild-caught & 12.67 & 6.53 & Sumiarsa (1994) \\
Hatchery-bred & 12.05 & 6.57 & Sumiarsa (1994) \\
Hatchery-bred & 13.44 & - & Prijono et al. (1993) \\
Hatchery-bred & 10.48 & - & Aslianti et al. (1993b) \\
\hline
\end{tabular}


Aslianti, T.; T. Ahmad; A. Prijono; dan 'T. Setiadharma. 1993b. Pengaruh pemberian ransum yang berbeda terhadap kelangsungan hidup larva bandeng, Chanos chanos Forsskal. J. Penelitian Budidava Pantai. 9 (1):59-66.

Bagarinao, T.U. 1991. Biology of milkfish (Chanos chanos Forsskal). Aquaculture Department. Southeast Asian Fisheries Development Center. Tigbauan Ilo-ilo Philippines, $94 \mathrm{pp}$.

Brett, J.R. 1979. Environmental factors and growth, pp.559-875. In. Fish physiology. Hoar, W.S, D.J. Randall and J.R Brett (eds). Academic Press, Inc., New York.

Durve, V.S. 1986. Some observations on the condition-ed responses of the fingerling of the milkfish (Chanos chanos Forsskal). Proc. Indian Acad. Sci. 68B : 69-79.

Fernald. R.D. 1985. Growth of the teleost eve. Novel solutions to complex constraints. Environ. Biol. Fishes. 13:113-12:3.

Giri. N.A.; A. Prijono: dan Tridjoko. 1986. Pemijahan dan pemeliharaan larva bandeng (Chanos chanos). Jurnal Penelitian Budidaya Pantai 2. (1\& 2): 13-18.

Guthrie, D.M. 1986. Role of vision in fish behaviour pp.75-113 In, The behaviour of teleost fishes, Pitcher T.J.(ed). Croom Helm, London.

Halsey, W.P.; L. Shores; R.H. Blackburn; and S.F Francis. 1974 Colliers Encyclopedia. P.F. Collier Co. Sond Ltd. Canada F: Vol 7:2.7.

Kawamura, (i. 1984. The sense organs and behaviour of milkfish fry in relation to collection techniques, pp.69-84 In. Advances in milkfish biology and culture, Juario, J.V. R.P. Ferraris and L.V. Bemtez (eds). Island Publ. House, Manila.
Kawamura, G. and S. Hara. 1980. On the visual feeding of milkfish larvae and juveniles in captivity. Bull. Jpn. Soc. Sci. Fish. 46 : $1297-1300$.

Kawamura, ( 1 . and W. Nishimura 1980 $S$-potential from the retina of milkfish, Chanos chanos Forsskal. Bull. Jpn. Soc. Sci Fish $16: 1421$.

Kawamura, G. and Y. Shimada. 1980 Change in phototactic behaviour with growth of milkfish. Chanos chanos (Forsskal). Kagoshima Univ. Res. Cent. S. Pac. I: 75-87.

Lythgoe, J.N. 1980. Aspects of photoreception in aquatic environments Symp. Soc. Exp. Biol. $39: 515-556$.

Munz, F.W. 1971. Vision: visual pigments. Vol. V. pp.1-3. In, Fish physiology. Hoar W.S. and D.J. Randall (eds). Academic Pres, Inc. New York.

Noakes, I.L.G. and J.G.J. Godin. 1988. Ontogeny of behaviour and concurrent developmental changes in sensory systems in teleost fishes. Vol. XI, pp. 345-395. In, Fish physiology, Hoar W. S. and P.J. Randall (eds). Academic Pres, Inc. New York

Ostrowski. C.A. 1989. Effect of rearing tank background colour on early survival of dolphim larvae. The Progressive Fish Culturist $51: 161-163$.

Prijono, A.: T. Ahmad: dan T. Setiadharma. 1993. Tanggapan larva bandeng, Chanos chanos Forsskal terhadap pakan buatan. J. Penelitian Budidaya Pantai. 9 (1): 91-98.

Sumiarsa. G.S. 1994. Tolerance of the hatchery-bred and natural milkfisk fry. J. Penelitian Budidaya Pantai. 9 (1): 85-94.

Yamaguchi, M. 1978. Practical culture method of red seabream. Koseikoku, Japan. 30p. 